Piotr Kostyto*

Bydgoszcz

\title{
Ferdinand Ebner i paradoks samotności
}

Bertrand Russell we Wprowadzeniu do swoich Dziejów filozofii Zacho$d u$ pisze, że zrozumienie historycznej epoki czy narodu wymaga zrozumienia jego filozofii ${ }^{1}$. Filozofia Ferdinanda Ebnera rzuca bardzo wiele światła na epokę obejmującą przełom XIX i XX wieku i nazywaną europejskim modernizmem. Pozwala ona także lepiej zrozumieć kulturę monarchii austro-węgierskiej w dobie kryzysu poprzedzającego wybuch I wojny światowej, tragedii działań wojennych, a także będącego wynikiem wojny rozpadu państwa. Ebner był świadkiem tych wydarzeń, a także ich stałym komentatorem. W jego książkach, listach i prywatnych dziennikach znajdujemy zapis zarówno głębokiego kryzysu współczesnej mu kultury, jak i stanu jego umysłu zmuszonego do zmagania się z własnymi niepokojami ${ }^{2}$. Ebner przeczuwał nadchodzący kres świata, w którym żył, i proponował drogę ocalenia. Ocalenie to według niego miało nadejść dzięki słowu rozumianemu w sposób duchowy, jak sam mówił, pneumatologiczny. Była to propozycja religijna, osadzona w wierze chrześcijańskiej i wymagająca takiej samej wiary od innych.

* Dr hab. Piotr Kostyło, prof. UKW, jest kierownikiem Zakładu Filozofii Edukacji i Metodologii Badań w Instytucie Pedagogiki Uniwersytetu Kazimierza Wielkiego w Bydgoszczy. Adres: Instytut Pedagogiki UKW, ul. Chodkiewicza 30, 85-064 Bydgoszcz; adres e-mail: piotr.kostylo@ukw.edu.pl.

${ }^{1}$ Bertrand Russell, Dzieje filozofii Zachodu (Warszawa: Fundacja Aletheia, 2000), 10.

${ }^{2}$ Spośród bogatej spuścizny Ebnera w niniejszym artykule przywołuję przede wszystkim koncepcje zawarte w książce pt.: Słowo i realności duchowe. Fragmenty pneumatologiczne. 
Odwołanie się do Russella w pierwszym zdaniu nie jest przypadkowe. W przywołanej książce stawia on kilka innych tez, które okazują się pomocne w osadzeniu myśli Ebnera w historii filozofii, a także w interpretacji tej myśli. Pisze na przykład o tym, że filozofia jest czymś pośrednim między teologią i nauką. Związki myślenia Ebnera z teologią są oczywiste, niemniej, jak wskazują znawcy spuścizny austriackiego filozofa, nie należy tracić z pola widzenia odniesień tego myślenia do nauki, zwłaszcza językoznawstwa. Najważniejsza teza Russella dotyczy jednak czegoś innego. Brytyjski filozof sugeruje, by dzieje filozofii Zachodu interpretować jako ciag sporów między podejściem kolektywistycznym i indywidualistycznym do kultury, zwłaszcza religii i polityki. Na dwóch przeciwstawnych biegunach sytuują się tu spoistość społeczeństwa i wolność jednostki. Nastawienie na spoistość społeczeństwa towarzyszyło zazwyczaj tym kierunkom filozoficznym, które rozwijały się w atmosferze bezpieczeństwa i dobrobytu, charakteryzowały się optymizmem i otwartością na przedsięwzięcia wspólnotowe. Nacisk na wolność jednostki pojawiał się, przeciwnie, w koncepcjach propagowanych w czasach zagrożeń i niedostatku, towarzyszył nastrojom pesymistycznym i dekadenckim. W tym kontekście myśl dialogiczna Ebnera wpisuje się wyraźnie w ten drugi nurt.

W niniejszym tekście rozważam wybrane aspekty myśli Ebnera z punktu widzenia teologii oraz filozofii, kładąc nacisk na ich znaczenie edukacyjne. Zastanawiam się, jaki model edukacji religijnej wyłania się z filozofii austriackiego myśliciela, a także w jakim stopniu model ten może być zrealizowany w systemie szkolnym współczesnego państwa liberalno-demokratycznego. Pytanie o wkład Ebnerowskiej myśli dialogicznej do praktyki edukacyjnej jest jak najbardziej zasadny. Filozofia dialogu już wielokrotnie potwierdzała swoją przydatność w naukach społecznych oraz w praktyce wyłaniającej się z tych nauk³ . Ebner jest z pewnością myślicielem mniej znanym od Martina Bubera czy Franza Rosenzweiga, niemniej jego analizy wciąż wzbudzają zainteresowanie w jego rodzinnej Austrii, a także za granica. Nie bez znaczenia jest fakt, że przez cały okres swojego życia zawodowego Ebner był nauczycielem w szkole podstawowej, a przez pewien czas sprawował funkcję dyrektora szkoły.

Niniejszy tekst jest zbudowany w ten sposób, że najpierw przedstawiam Ebnerowską koncepcję religii i kultury, podkreślając napięcie między jed-

3 Jako przykład wykorzystania podejścia dialogicznego w psychologii można wskazać podręcznik psychologii komunikacji pod redakcją Johna Stewarta pt. Mosty zamiast murów 
nym i drugim. W drugim punkcie porównuję ze sobą dialog religijny, tak jak rozumiał go Ebner, z dialogiem politycznym, tak jak jest on rozumiany współcześnie, w praktyce funkcjonowania państwa liberalno-demokratycznego. Wreszcie, w trzecim punkcie przedstawiam specyfikę doświadczenia religijnego w ujęciu Ebnera, by zakończyć kilkoma myślami na temat edukacji religijnej właściwej dla tej filozofii dialogu.

\section{Religia i kultura}

Relacja religii i kultury jest jedną z najciekawszych kwestii analizowanych przez teologię i filozofię religii. Stajemy tu wobec pytania, jak relacja człowieka do Boga ma się do jego relacji do świata? W chrześcijaństwie różnie na to pytanie odpowiadano. Zazwyczaj podkreślano jakąś formę obecności Boga w świecie, dążono nawet do dowiedzenia tej obecności na podstawie zjawisk zachodzących w życiu jednostek i wspólnot; niekiedy jednak przypominano o zasadniczej odmienności Boga i świata, wskazywano, że człowiek wierzący żyje w świecie jak na wygnaniu i oczekuje na zjednoczenie z Bogiem, które nastąpi dopiero po śmierci. Do tych dwóch różnych podejść odnoszą się analizy Russella, o których wspomniałem powyżej. Mamy tu do czynienia z dwiema postawami wobec społeczeństwa i kultury - pierwszą, która charakteryzuje się otwartością na innych ludzi i chęcią współtworzenia z nimi świata, oraz drugą, wyrażającą się w zamknięciu się na innych i skupieniu na własnej psychice i tym wszystkim, czego w niej doświadczamy. $\mathrm{Z}$ tej dwoistości, jak widzieliśmy, Russell wywodzi dalekosiężne wnioski, tłumacząc nią nie tylko zachowania pojedynczych osób, ale także zmienne orientacje filozoficzne w poszczególnych epokach historii. Powiedziałem, że myślenie Ebnera sytuuje się w tej drugiej orientacji.

Tym, co uderza w tekstach Ebnera, jest obecne w nich przekonanie, że współczesna kultura wyczerpała już swoje możliwości i jest skazana na unicestwienie. Przebija w nich pewien fatalizm co do losów świata, który Ebner znał do tej pory. Fatalizm ten jest niekiedy tłumaczony osobowością samego Ebnera, a także stanem jego zdrowia, ciagłym zagrożeniem poważną chorobą, z którym musiał się zmagać. To tylko częściowo wyjaśnia nastawienie myśliciela. O wiele ważniejszym powodem tych pesymistycznych rozważań

(Warszawa: PWN, liczne wydania). Redaktor podręcznika we wstępie wprost deklaruje inspiracje filozofią Martina Bubera. 
była intuicja zbliżającego się kresu monarchii i konstytuowanej przez nią wspólnoty politycznej. Ta intuicja przekształcała się niemal w empiryczną pewność wraz z rozwojem wypadków na frontach I wojny światowej. Ebner śledził z niepokojem pogłębiającą się dezintegrację monarchii i coraz wyraźniej zdawał sobie sprawę, że jest to proces nieunikniony. Austro-Węgry, potężne państwo, które, rozciagając się na ogromnej przestrzeni i obejmując wiele narodów, odgrywało kluczową rolę w XIX-wiecznej Europie, przestawało istnieć. Ci obywatele monarchii, którzy przez cały miniony wiek utożsamiali się z Państwem, choć wywodzili się z różnych kultur i mówili różnymi językami, zaczynali szukać własnej drogi rozwoju, żądali wolności i suwerenności. Ebner widział, że nie było już szans na uratowanie dotychczasowej wspólnoty politycznej. Wyciągnął z tego wniosek, że nie ma szans również na uratowanie wspólnoty religijnej. Było tak dlatego, że wspólnota ta ściśle przenikała się ze wspólnotą polityczną, religia stanowiła integralną część głównego nurtu kultury, a Kościół konsekwentnie trwał przy boku Państwa, gwarantując nienaruszalność społecznego status quo, nadając mu w istocie nadprzyrodzoną sankcję ${ }^{4}$. Nieuchronność zbliżającej się zmiany, która dla wielu, zapewne także dla Ebnera, miała charakter katastrofy, sprawiła, że naglące stało się pytanie o możliwości przetrwania, uniknięcia ostatecznej dezintegracji. Dla Ebnera źródłem nadziei stała się religia, nie ta religia, którą znał z oficjalnych ceremonii, bliska Państwu i jego instytucjom, ale religia wewnętrzna, indywidualistyczna, przemawiająca do serca człowieka. Ebner pisał: „Dlatego też ten, kto żyje naprawdę życiem ducha,

${ }^{4} \mathrm{~W}$ polskich tekstach przedstawiających sytuację społeczną pod zaborem austriackim na przełomie XIX i XX wieku podkreśla się konserwatyzm i hierarchiczność stosunków społecznych panujących wówczas w Austro-Węgrzech. Magdalena Micińska w pracy poświęconej losom inteligencji polskiej żyjącej pod zaborami pisze: „Zarazem jednak hierarchiczność stosunków społecznych Galicji - w tym zwłaszcza dominująca pozycja arystokracji i kleru katolickiego - determinowała pozycję inteligencji i jej uzależnienie od warstw utytułowanych. «Inteligencja to niemowlę skrępowane w powijaki polityki i kultury szlacheckiej», narzekał Franciszek Bujak, opisując rzeczywistość zachodnich powiatów kraju, przede wszystkim Krakowa. Więzy te słabły w stołecznym Lwowie. Tam jednak największy prestiż przypisany był do stanowisk w administracji krajowej, w której panowały duch feudalizmu, bałwochwalcze zamiłowanie do rang i tytułów, niechęć do jakichkolwiek przejawów indywidualizmu. W takim kastowym, zatrzymanym w czasie świecie - jak diagnozował jeden z galicyjskich publicystów - szeregowy kancelista na stałej posadzie ważył więcej niźli przenikliwy pisarz czy rzutki działacz społeczny". Magdalena Micińska, Inteligencja na rozdrożach (Warszawa: Instytut Historii PAN, Wydawnictwo Neriton, 2008), 152-153. Wiele wskazuje na to, że z podobnymi stosunkami społecznymi miał do czynienia Ebner. 
nie powołuje się też nigdy na naród, do którego należy w ramach związania swej egzystencji z ziemią"'.

Lektura tekstów Ebnera, a także tekstów na temat jego twórczości, pokazuje, że często stosunek austriackiego myśliciela do kultury był ambiwalentny. $Z$ jednej strony przyswajał on sobie jej dokonania, można powiedzieć, chłonął ją pełną piersią, o czym świadczą jego regularne wizyty w wiedeńskich muzeach, salach koncertowych czy teatrach, jego bogate i zróżnicowane lektury, czy to książek, czy czasopism, a także jego liczne osobiste znajomości i przyjaźnie z wybitnymi przedstawicielami ówczesnej kultury i sztuki ${ }^{6}$. Trudno więc powiedzieć, że Ebner odrzucał kulturę en bloc, że był nieprzejednanym wrogiem wszystkich jej przejawów. $Z$ drugiej strony jest jasne, że były takie przejawy kultury, z którymi myśliciel austriacki absolutnie nie mógł się zgodzić. Rysem kultury, który wzbudzał jego najgłębszy sprzeciw, były bliskie związki państwa i religii. Religia jako element kultury, spleciona nierozerwalnie z instytucjami państwa, przekształcała się według Ebnera w swoją własną karykaturę. Zjawisko to stawało się coraz wyraźniejsze wraz z rozwojem działań wojennych na frontach I wojny światowej. Jako nauczyciel Ebner często uczestniczył w uroczystościach państwowych, które miały zarazem wydźwięk religijny, jak i w uroczystościach religijnych, które były obowiązkowe dla funkcjonariuszy państwa. Oto co na ten temat pisze jeden ze znawców twórczości Ebnera:

Zobowiązany jako nauczyciel do uczestniczenia w procesjach Bożego Ciała, które uświęcały sojusz tronu z ołtarzem, Ebner nie mógł znieść widoku lotników nagradzanych żelaznymi krzyżami, ani wysadzanych klejnotami krzyży zdobiących rycerzy świeckiego zakonu. Podobnie jak Haecker, ten antynomicznie nastawiony myśliciel potępiał użycie krzyża do błogosławienia broni, zarzucając kościołowi łączenie się ze społeczeństwem skoncentrowanym na ego ${ }^{7}$.

Tym, co doprowadziło Ebnera do takiej postawy, była troska o czystość wiary. Krytykując religię jako zjawisko kulturowe, austriacki myśliciel wy-

${ }_{5}^{5}$ Ferdinand Ebner, Stowo i realności duchowe. Fragmenty pneumatologiczne (Warszawa: IFiS PAN, 2006), 225.

${ }^{6} \mathrm{Na}$ żywe i twórcze zainteresowanie Ebnera współczesną kulturą zwraca uwagę Walter Methlagl w tekście zamieszczonym w niniejszym numerze Paedagogia Christiana.

7 William M. Johnston, The Austrian Mind. An Intellectual and Social History 1848-1938 (Berkeley-Los Angeles-London: University of California Press, 1983), 219. 
stępował przeciwko filozofii idealistycznej Hegla, sytuował się w opozycji do tych myślicieli, którzy rozwijając tę filozofię szukali jakiejś syntezy między religią a kulturą, próbowali uzgodnić dążenia jednostek z dążeniami ogółu. Dla Hegla i jego uczniów religia oznaczała swego rodzaju konwergencję, zasadę ujednolicającą, która miała zagwarantować zbliżanie się do siebie jednostek, osiaganie kompromisu między ich autonomicznymi pragnieniami i ambicjami ze względu na dobro wspólne. Taka synteza religii i kultury, według Ebnera, musiała prowadzić ostatecznie do podporządkowania jednostki państwu, do uznania całkowitej zależności, w istocie ontologicznej podległości tejże jednostki wobec wspólnoty. Myśliciele, którzy forsowali taką argumentację, przekonywali, że zbliżenie religii i polityki, ścisła współpraca Kościoła i Państwa, będzie antidotum na wzrastające wpływy środowisk laickich i liberalnych, a przede wszystkim, w okresie konfliktu zbrojnego, pozwoli skupić całe społeczeństwo wokół Cesarza i jego polityki. Uważali, że religia przyniesie usprawiedliwienie dla działań politycznych i militarnych Państwa, natomiast Państwo potrafi ochronić religię, skłonić wszystkich obywateli do jej szanowania. Aby zachować tradycyjne miejsce dla religii w społeczeństwie, byli gotowi zaakceptować protektorat władzy, udzielić zgody Państwu na wykorzystywanie religii do własnych, niemających często nic wspólnego z religią celów. Ebner zdawał sobie sprawę, że cena, jaką religia musi płacić za ten protektorat, jest zbyt duża ${ }^{8}$.

W teologii niekiedy mówi się w związku z tym o dwóch religiach: religii św. Pawła oraz religii św. Jana. Pierwsza byłaby otwarta na świat, dynamiczna i wspólnotowa, druga, przeciwnie, opierałaby się na nieufności do świata, byłaby raczej bierna i indywidualistyczna. W pierwszej religii kluczowe byłoby budowanie wspólnoty i orientacja na ulepszanie świata, w którym się żyje, w drugiej - dążenie do wewnętrznego samodoskonalenia się i oczyszczenia w oczekiwaniu na nadchodzący kres życia. Dwie rozwijające się równolegle w chrześcijaństwie tradycje, ta nawiązująca do listów apostolskich św. Pawła oraz ta przywołująca aktualność Apokalipsy św. Jana, są dobrą ilustracją różnicy, o której tu mówimy. Św. Paweł rzuca wyzwanie światu i jego kulturze, chce z nim prowadzić spór, zadaje mu pytania i oczekuje odpowiedzi. Ogólna wymowa jego listów jest taka, że kultura stworzona

${ }^{8}$ Interesujące analizy w związku z tą kwestią przedstawia Krzysztof Skorulski w artykule „Od ideologicznej samotności do dialogicznego spotkania: F. Ebner, L. Althusser, P. Freire”, Forum Oświatowe 1 (2014): 15-35. Pisze w nim m.in. o ideologii jako narzędziu ujednolicenia i niwelowania różnic między jednostkami żyjącymi w społeczeństwie. 
przez ludzi nie może być całkowicie odrzucona, ale powinna być przekształcona zgodnie $z$ zasadami nowej religii. $W$ tym przekształcaniu chrześcijanie powinni uwzględniać istniejące już reguły, między innymi reguły funkcjonowania państwa. Św. Jan odwraca się od kultury, widząc w niej siedlisko wszelkiego zła i zepsucia, i czyni to w przekonaniu o nadchodzącym końcu świata. U św. Pawła dominuje postawa wspólnotowa, u św. Jana indywidualistyczna.

To, że Ebner odwołuje się w swoich tekstach do Słowa, Logosu w rozumieniu św. Jana, wiele mówi o jego postrzeganiu chrześcijaństwa. Było ono bardziej Janowe niż Pawłowe. Ebner nie zwrócił się ku religii Pawłowej, gdyż projekt ożywienia i wzmocnienia religii na poziomie społecznym, znalezienia korzystnego dla wierzących modus vivendi z Państwem był niemożliwy do zrealizowania. Ani Państwo, ani dominująca w nim kultura nie miały stabilności niezbędnej do budowania w ich ramach wspólnoty religijnej. Ebner pisał: „Cała kultura nie była dotychczas i nie będzie niczym innym jak snem o duchu, śnionym przez człowieka w «samotności Ja» jego

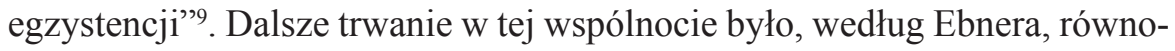
znaczne z trwaniem w iluzji co do własnego chrześcijaństwa, było podobne do marzeń sennych. Odnowa religijna mogła przyjść tylko z wnętrza człowieka, mogła się dokonać dzięki szczególnemu doświadczeniu obcowania ze Słowem pochodzącym od Boga. To właśnie o tym Słowie pisał w prologu swojej Ewangelii św. Jan, że było Ono na początku. Ebner stwierdzał: „Bóg jednak stworzył człowieka w ten sposób, że do niego przemówił. Stworzył go przez słowo, w którym było życie, a życie było światłością ludzi, jak napisane jest w Prologu Ewangelii według Świętego Jana"10. Początek ten może być rozumiany w sensie chronologicznym, ale ważniejsza jest jego interpretacja metafizyczna. W tym sensie Słowo to jest najważniejszym elementem rzeczywistości, tym, na czym opiera się wszystko, co istnieje. Jest to Słowo stwarzające świat i utrzymujące go w istnieniu. Jeżeli zatem coś ma uchronić ludzi od pogrążenia się w odmętach chaosu, od dezintegracji wraz z upadającym Państwem, jego kultura, a w jej ramach także dotychczas znaną religią, to może to być wyłącznie odwieczne Słowo. Dotychczas znana postać religii zanika, zdaje się prorokować Ebner, a jej miejsce zajmuje nowa postać, zarazem duchowa i realna.

\footnotetext{
9 Ebner, Stowo, 14.

${ }_{10}$ Tamże, 20.
} 


\section{Dialog religijny i dialog polityczny}

Dialog, tak jak rozumiał go Ebner, pełnił podwójną funkcję. Z jednej strony pozwalał nawiązać realne więzi z drugim człowiekiem, z drugiej umożliwiał uwolnienie się od dominującej w XIX wieku wizji nierozerwalnego związku Państwa i Kościoła. To oczywiście każe postawić pytanie o społeczną funkcję dialogu. Czemu ze społecznego punktu widzenia ma służyć dialog? Czy budowaniu wspólnoty, czy raczej wyzwoleniu się od niej? To pytanie jest zasadne, ale pozostawmy je w tej chwili bez odpowiedzi.

Ebner, podobnie jak wcześniej Søren Kierkegaard, przeciwstawiał się Heglowskiej wizji dialogu. Widać to wyraźnie w konstrukcji zasady dialogicznej, w potraktowaniu Ty przez Ja. Heglowska interpretacja spotkania dwojga osób zawiera w sobie wyraźne odniesienia dialogiczne, ale dialog jest tu rozumiany inaczej niż u Ebnera. Interpretując Trójcę Świętą w nurcie Heglowskim, można powiedzieć, że Ojciec wchodzi w dialog z Synem po to, by dowiedzieć się czegoś więcej o sobie, by rozpoznać samego siebie. Tego rodzaju dialog nie jest według Ebnera dialogiem prawdziwym. U Hegla Ja kieruje się do Ty nie po to, by poznać Ty, ale po to, by poznać siebie. $\mathrm{Ja}$, otwierając się na Ty, czyni to powierzchownie $\mathrm{i}$, można rzec, chwilowo, gdyż niebawem powróci do siebie ubogacone przez to, co rozpoznało w Ty. Ja ma w tym zwróceniu się do Ty swój własny interes, samopoznanie, przejrzenie się $\mathrm{w}$ odmienności Ty jak w lustrze po to, by wznieść się na wyższy poziom samoświadomości. Ty w takim rozumieniu jest traktowane instrumentalnie, jako środek prowadzący do celu, a nie jako cel sam w sobie. Takie zbliżanie się do drugiego, przeglądanie się w nim i powrót do siebie nie ma nic wspólnego z obcowaniem z prawdziwym duchem, uważał Ebner. To tylko sen o duchu. Śnimy o drugim, ale nie poznajemy go; pozostajemy na poziomie idei, daleko od realności. Heglowski dialog prowadzi do tego, że ostatecznie każda jednostka rozpoznaje w sobie i wokół siebie oddziaływanie ducha obiektywnego, uznaje to oddziaływanie i podporządkowuje się jemu; poprzez dialog mamy stać się do siebie podobni, pogodzić się z własnym życiem, ze sobą nawzajem i z historią. Wszystko to, co przypadkowe, niepowtarzalne i subiektywne, ma zostać usunięte. $Z$ tym nie zgadzali się i Kierkegaard, i Ebner. Na ten ważny aspekt myśli Ebnera zwrócił uwage między innymi amerykański filozof i teolog, specjalizujący się w filozofii procesu, John O’Donnell ${ }^{11}$.

${ }^{11}$ John O'Donnell, “The Trinity as Divine Community”, Gregorianum 69 (1988): 5-34. 
Ebner podkreśla, że dialog otwiera jednostkę na realność drugiego, a nie na to, co jednostka wyobraża sobie na jego temat. Na pierwszy rzut oka mogłoby się wydawać, że Ebnerowska zasada dialogiczna zbliża osobę do innych ludzi, a więc niesie w sobie optymistyczne założenie co do możliwości porozumienia z innymi, a także wartościowego życia i działania w grupie. Taka interpretacja byłaby jednak tylko częściowo poprawna. Bo o ile z pewnością prawdą jest, że w przekonaniu Ebnera postawa dialogu oznacza otwarcie się na drugiego człowieka i doświadczenie tak zwanych realności duchowych objawiających się w nim, o tyle nie można powiedzieć, by otwarcie to rozciagało się na jakąś wspólnotę, czy tym bardziej na całe społeczeństwo. Mamy tu raczej do czynienia ze spotkaniem dwojga osób, i tylko dwojga osób, które dzięki dialogowi budzą się ze swoistego snu, nazywanego przez Ebnera snem o duchu; nie prowadzi to jednak do żadnego spontanicznego nawiązywania więzi z kolejnymi osobami, z całą wspólnotą. Dialog buduje moje relacje $\mathrm{z}$ drugim, ale nie z grupa, zwłaszcza gdy grupie rodzinie, środowisku lokalnemu, narodowi czy ludzkości - przyznaje się status inny niż zwykłego zbioru jednostek. Ten ważny i kontrowersyjny wątek w myśli Ebnera został uwypuklony przez Krzysztofa Skorulskiego, który zauważył, że „niewątpliwie nieakceptowalna przez Ebnera” byłaby filozofia My, w której Ja i Ty stanowiłyby pewnego rodzaju jedność metafizyczną, tak jak ukazuje to w swojej myśli Gabriel Marcel ${ }^{12}$.

Przekonania Ebnera odnośnie do dialogu byłyby bliskie koncepcjom św. Augustyna, Pascala czy Johna Henry’ego Newmana. Św. Augustyn zachęcał swoich współwyznawców, aby w poszukiwaniu Boga zwracali się do swojego serca; Pascal pozostawił po sobie słynne powiedzenie: „Serce ma swoje racje, których rozum nie zna"; natomiast John Henry Newman umieścił na swoim kardynalskim herbie znane słowa św. Franciszka Salezego: cor ad cor loquitur (serce mówi do serca). Te zdania można różnie interpretować teologicznie, niemniej ich sens jest taki, że najgłębsza komunikacja między dwiema osobami dokonuje się na takim poziomie intymności, który jest niedostępny dla osób trzecich, a tym samym dla racjonalnej argumentacji. Dokonuje się ona za pomocą wyjątkowego słowa, które według Ebnera upodabnia się do ewangelicznego Logosu. Ebnerowska koncepcja dialogu sytuuje się więc w określonym nurcie tradycji chrześcijańskiej, ale trzeba pamiętać, że nie jest to nurt główny. Jest to raczej nurt właściwy dla misty-

${ }^{12}$ Krzysztof Skorulski, „Ferdinand Ebner i miejsce filozofii dialogu w myśli katolickiej XX wieku", Paedagogia Christiana 1 (2011): 63. 
ków i ich tajemniczego dialogu z Bogiem, nurt nieufny wobec świata, nurt zazdrośnie strzegący transcendencji Boga ${ }^{13}$.

Dialog, komunikacja społeczna, negocjacje to terminy, które na stałe weszły dziś do analiz teorii i praktyk społecznych. W pewnym sensie współczesne państwo liberalno-demokratyczne opiera się na dialogu, z jednej strony między rządzącymi a rządzonymi, z drugiej między różnymi partiami politycznymi, które w odmienny sposób chciałyby zorganizować życie społeczne. $Z$ tego punktu widzenia można powiedzieć, że takie przełomowe prace z zakresu filozofii politycznej jak Teoria dziatania komunikacyjnego Jürgena Habermasa czy Teoria sprawiedliwości Johna Rawlsa są traktatami o dialogu. Trzeba jednak pamiętać, że dzisiejsze państwo różni się pod wieloma istotnymi względami od państwa, które znał Ebner. Trudno byłoby wymienić wszystkie te względy, niemniej jeden wydaje się szczególnie ważny pogłębiający się rozdział Państwa od Kościoła. Jest on ważny w przypadku analiz myśli Ebnera dlatego, że, jak widzieliśmy, przenikanie się spraw państwowych i kościelnych, polityki i religii było na początku XX wieku trwałym elementem kultury monarchii austro-węgierskiej i czymś, co radykalnie krytykował austriacki myśliciel. Dziś obecność religii w sferze publicznej zanika, a instytucjonalne związki Państwa i Kościoła są czymś wyjątkowym, zależnym całkowicie od woli Państwa. Nie można powiedzieć, że separacja Państwa i Kościoła wszędzie jest traktowana w sposób absolutny, zazwyczaj stosunki między obu podmiotami są regulowane poprzez umowy, w których bierze się pod uwagę przede wszystkim możliwości współpracy stron dla dobra wspólnego. Niemniej to Państwo jest stroną silniejszą w tych umowach, to ono decyduje, jaki zakres autonomii pozostawić instytucjom religijnym i w jakiej mierze uwzględnić etyczne normy religii w swoim własnym prawodawstwie.

Dużym błędem byłoby przenoszenie analiz Ebnera dotyczących dialogu na rozumienie tego zjawiska dziś, w kontekście filozofii społecznej i politycznej. Dla Ebnera dialog miał charakter religijny, duchowy i subiektywny, był wyrazem maksymalistycznego podejścia do życia jednostek i jego interpretacji, w tym sensie, że gwarantował sens życia i ocalenie w obliczu dez-

13 Ten sposób postrzegania spotkania i dialogu dwojga osób nie wpisuje się w nurt myślenia tomistycznego i neotomistycznego. W tym nurcie tradycyjnie podkreślano znaczenie racjonalnych podstaw komunikacji osób, a także wskazywano na komunikację jako źródło tworzenia i wzmacniania wspólnoty. O roli kształtowania cnót społecznych w pedagogice neotomistycznej pisze w swojej ostatniej książce Jarosław Horowski: Wychowanie moralne wedlug pedagogiki neotomistycznej (Toruń: Uniwersytet Mikołaja Kopernika, 2015). 
integrującego się świata i jego kultury. Dla takich myślicieli jak Habermas i Rawls dialog jest zjawiskiem świeckim, odnoszącym się do organizacji życia społecznego i obiektywnym, nie rości sobie pretensji do odpowiadania na najgłębsze troski jednostki, ani do wybawiania jednostek z kryzysów kultury. Dzisiejszy dialog w sferze publicznej ma raczej charakter proceduralny, nie materialny, to znaczy poszukuje się w nim zasad, które zostaną zaakceptowane przez wszystkich i pozwolą racjonalnie i bezpiecznie negocjować konkretne rozwiązania społeczne w przyszłości. Nie chodzi w nim o to, jak ma być, ale o to, według jakich zasad mamy działać, aby wspólnie dojść do odpowiedzi na to pytanie. U źródeł tak rozumianego dialogu leży krytyka autorytetu, opór wobec sytuacji, w których ktoś z góry przesądza o kierunku rozwoju życia społecznego. Dialog w państwie liberalno-demokratycznym ma wymiar minimalistyczny w tym sensie, że ogranicza się do niezbędnego minimum w relacjach między jednostkami, czyli do takich zasad, których przyjęcie jest absolutnie konieczne ze względu na sprawne funkcjonowanie państwa i wspólnoty obywateli. Widać to wyraźnie na przykładzie sytuacji pierwotnej wypracowanej przez Rawlsa. W tej sytuacji, hipotetycznie, znajdują się wszyscy obywatele państwa, nie wiedząc, jakie faktycznie role pełnią $\mathrm{w}$ tym państwie, jakie pozycje $\mathrm{w}$ nim zajmują $\mathrm{i}$ jakie perspektywy się przed nimi otwierają. Pytanie, na jakie muszą w tej sytuacji odpowiedzieć, dotyczy zasad, na które wszyscy z nich zgodziliby się bez sporów. Rawls proponuje dwie takie zasady: pierwsza - respektowanie praw nabytych oraz drugą - równy dostęp do pozycji i zaszczytów, a także wdrażanie takich zmian społecznych, które byłyby najkorzystniejsze dla najsłabszych. Respektowanie tych zasad w dialogu między rządzącymi i rządzonymi gwarantuje zachowanie bezstronności państwa, a tym samym neutralności wobec rozmaitych wartości, także wartości religijnych, które mogą być afirmowane przez jednostki lub grupy.

Dialog religijny, tak jak rozumiał go Ebner, nie jest w ogóle przywoływany w funkcjonowaniu państwa liberalno-demokratycznego. To, gdzie poszczególne jednostki - obywatele tego państwa - znajdują najgłębszy sens swojego życia, skąd czerpią poczucie szczęścia i spełnienia, jest w istocie mało ważne dla państwa, jak długo podporządkowują się one zasadom w nim obowiązującym. Dialog jest konieczny, ale tylko po to, by unikać kolizji interesów i nierozwiązywalnych sporów. Warto zauważyć, że problematyka religijna nie jest przedmiotem tego dialogu i że nie dzieje się tak przez przypadek. Doświadczenia historyczne uczą bowiem, że, po pierwsze, kontrowersje religijne nie są rozstrzygalne za pomocą żadnych racjonalnych argumentów oraz po drugie - nawarstwianie się tych kontrowersji prowadzi 
do wzrostu napięć społecznych, a niekiedy nawet do prześladowań i wojen religijnych. Im mniej religii w sferze publicznej, tym mniejsze ryzyko wystąpienia tych zagrożeń. Ale czy w istocie nie o to chodziło Ebnerowi? Czy konstruując swoją koncepcję dialogu, duchowego i subiektywistycznego, nie dążył do uwolnienia sfery publicznej od religijnego pustosłowia? Czy nie jest tak, że sprowadzenie religii do sfery ściśle prywatnej jest ceną, jaką religia, zdaniem Ebnera, musi zapłacić za swoją czystość? Zatem usunięcie wątków religijnych z dialogu i komunikacji rozwijanej we współczesnym państwie byłoby dokładnie tym, czego oczekiwał Ebner. W tym sensie dialog religijny byłby zarazem otwarciem się na drugiego, jak i zamknięciem się na społeczeństwo.

\section{Doświadczenie religijne i edukacja religijna}

Zasada dialogiczna otwiera jednostkę na najgłębsze doświadczenie religijne, pozwala dostrzec w drugim człowieku nieredukowalną wartość osobową. Dzięki tej zasadzie jednostka jest w stanie patrzeć na innych oczami Boga, dostrzegać ich wyjątkowość i niepowtarzalność. Mamy tu do czynienia, powtórzmy, z podejściem maksymalistycznym w tym sensie, że, po pierwsze, oczekuje się od jednostki wiary religijnej, po drugie zaś - w ramach tejże wiary - szczególnego rodzaju doświadczenia wewnętrznego, o którym niewiele pewnego można powiedzieć. Szukając bliskich odniesień dla tego doświadczenia, można przywołać na przykład kategorię intuicji, tak jak rozumiał ją Henri Bergson. Ebner czytał teksty Bergsona i, jak twierdzą znawcy filozofii Ebnera, był pod ich wpływem. Bergson pisał o trwaniu rzeczywistym, nazywając $\mathrm{w}$ ten sposób stan świadomości, w którym dochodzą do niej dane bezpośrednie pozwalające na uchwycenie realnie upływającego czasu. Inną kategorią bliską doświadczeniu, o którym mówi Ebner, jest miłość osobowa w ujęciu Karola Wojtyły. Wojtyła, podobnie jak inni personaliści, podkreślał, że miłość między kobietą i mężczyzną ujawnia się w trzech wymiarach: zmysłowym, uczuciowym i osobowym. Dopiero włączenie do miłości trzeciego wymiaru sprawia, że staje się ona pełna i upodabnia się do miłości Boga do ludzi. W tym punkcie widać wyraźnie bliskość filozofii dialogu i personalizmu. Można by przywołać również inne kategorie filozoficzne lub etyczne, które rzuciłyby trochę światła na istotę tego doświadczenia religijnego, o którym mówił Ebner. Myślenie Ebnera nie było więc czymś wyjątkowym w tradycji filozoficznej i religijnej, choć, jak zaznaczyłem, nie reprezentowało dominującej orientacji. 
Ebner z naciskiem twierdzi, że autentyczne doświadczenie religijne jest zawsze subiektywne. To, czego doświadcza jednostka w spotkaniu z Bogiem i drugim człowiekiem, nie może być w wiarygodny sposób zobiektywizowane, wyniesione na poziom ogólności. Kiedy jednostka próbuje usytuować się na takim ogólnym poziomie, natychmiast traci kontakt ze swoim życiem duchowym, zapada w sen. Wyjątkowość i niepowtarzalność doświadczenia religijnego jest warunkiem więzi z realnym życiem. Zauważmy, że w wielu przypadkach to szczególne doświadczenie religijne przynosi bardzo pozytywne rezultaty. Jednostki dzięki religii odnajdują sens życia, zyskują energię umożliwiającą im podejmowanie lub kontynuowanie trudnych przedsięwzięć, nabierają entuzjazmu w sytuacjach kryzysowych, jednym słowem, chcą dalej żyć. Zewnętrznym obserwatorom trudno wówczas ocenić, czy doświadczenie to było autentyczne, czy nie, czy jednostka weszła w kontakt $\mathrm{z}$ realnym, transcendentnym Bytem, czy może $\mathrm{z}$ własnymi wyobrażeniami i iluzjami na Jego temat. W pewnym sensie jest to rzecz drugorzędna. Rezultaty, jakie doświadczenie to przynosi, są pozytywne, i to przede wszystkim się liczy. Dobrym uzasadnieniem tego podejścia jest pragmatyzm Williama Jamesa i konstytutywne dla niego założenie, że ludzie patrzący z zewnętrz na życie jednostki nie są w stanie uchwycić najgłębszych znaczeń tego życia, a więc także ocenić go w sposób adekwatny. To stwierdzenie jest prawdziwe, jak sądzę, także w odniesieniu do doświadczenia dialogicznego w ujęciu Ebnera.

Niepowtarzalność i różnorodność doświadczeń religijnych, jak powiedziałby James, ma jednak swoją cenę. Uniemożliwia uczynienie z religii ujednolicającej zasady, która porządkowałaby i nadawała kierunek życiu społecznemu. Prawdziwe doświadczenie religijne, tak jak rozumie je Ebner, ma wymiar indywidualny, nie zbiorowy; egzystencjalny, nie kulturowy. Kładąc akcent na relacji Ja i Ty, nie rości sobie ono pretensji do oddziaływania na całe społeczeństwo. W ten sposób religia świadomie wycofuje się ze sfery kultury i z tych wszystkich iluzji, w których trwała, zwłaszcza w obszarze polityki. Doświadczenia religijne, które umożliwiały to trwanie, były nierealne, a więc fałszywe. To właśnie one tak frustrowały Ebnera i budziły jego odrazę. Permanentne legitymizowanie Państwa przez Kościół, uzasadnianie czy wręcz błogosławienie decyzji politycznych przez autorytety religijne, język religijny spleciony nierozerwalnie z językiem politycznym - wszystko to miało przekonywać całe społeczeństwo o uczestnictwie we wspólnym doświadczeniu religijnym, miało stanowić spoiwo ideologiczne monarchii.

Odrzucenie przez Ebnera takiego doświadczenia religijnego i uznanie za autentyczne jedynie tego, co indywidualne i subiektywne, zdaje się defi- 
nitywnie rozstrzygać kwestię dostępności doświadczenia religijnego w sferze publicznej w ogóle. Niemożność publicznego ukonstytuowania takiego doświadczenia nieoczekiwanie zbliża Ebnera do współczesnych zwolenników liberalizmu w tym sensie, że każe z najwyższą nieufnością patrzeć na próby mieszania religii z kulturą, zwłaszcza z polityką. I Ebner, i liberałowie zgadzają się co do tego, że odwołania do religii w sferze publicznej są niewłaściwe. Według Ebnera wstrzemięźliwość ta jest niezbędna ze względu na czystość religii, według liberałów rozdział religii i polityki ma chronić społeczeństwo przed fundamentalizmem religijnym. W jednym i drugim przypadku końcowy efekt jest podobny - ze sfery publicznej stopniowo znikają odniesienia religijne.

Doświadczenie religijne w ujęciu Ebnera ma charakter wyzwalający i pocieszający. Wyzwala z ciemności i pociesza w cierpieniu. Ebner tak o tym pisze:

W każdym życiu ludzkim jest niewątpliwie pewna ciemność, ciemność cierpienia w ułomności życia, ta jednak nie jest jedyna i nie jest najciemniejsza. Jej wnętrze rozjaśnia swym światłem wola poznania, która niesie pytanie „Dlaczego?”. Na próżno jednak Ja, w samotności poznawania, uderza w „,mur chiński” swojej egzystencji, o który rozbija się życie - pochodnia gaśnie i ciemność jest większa niż kiedykolwiek ${ }^{14}$.

Ułomność naszego życia, sama w sobie, jest dla nas źródłem cierpienia, ale tym, co najbardziej bolesne, zauważa Ebner, jest niemożność znalezienia odpowiedzi na pytanie, dlaczego cierpimy. Tej odpowiedzi jednostka nie znajdzie tak długo, jak długo nie otworzy się w doświadczeniu dialogu i miłości na drugiego. Bez tego dialogu i tej miłości życie jednostki jest „uderzaniem w mur chiński". Zauważmy, że tego rodzaju rozważania nie pojawiają się w liberalnych analizach dotyczących doświadczenia sensu życia. Liberalnie nastawieni myśliciele nie określają w tak jednostronny sposób warunków, jakie trzeba spełnić, aby być szczęśliwym i spełnionym. Są oni zwłaszcza dalecy od tego, aby uzależniać doświadczenie wyzwolenia wyłącznie od przeżycia religijnego. Prawdą jest oczywiście, że w wielu przypadkach doświadczenie religijne jest źródłem szczęścia, ale nie można twierdzić, że każde doświadczenie szczęścia ma swoje źródło w religii. W tym sensie Ebner pokazuje pewną drogę, która w jego życiu okazała się drogą ocalenia.

${ }^{14}$ Ebner, Stowo, 73. 
Tego typu doświadczenia są jednak traktowane z nieufnością przez społeczeństwo, które lęka się, że specyficzne doświadczenie religijne, mogące, owszem, pełnić pozytywną rolę w relacji między dwojgiem osób, może stać się nieoczekiwanie standardem wyznaczającym oczekiwania wobec wszystkich. Habermas w eseju o granicy między wiarą a wiedzą, odwołując się do myśli Kierkegaarda, pisze: „Kierkegaard radykalizuje przeciwieństwo między rozumem a religią, ale czyni to z punktu widzenia wiary objawionej. Jednocześnie zwraca transcendentalne samoograniczenie rozumu przeciwko jego własnemu antropocentryzmowi. To nie rozum narzuca granice religii, lecz doświadczenie religijne wskazuje granice rozumowi" ${ }^{15}$. Tego rodzaju założenie, tylko częściowo właściwe dla filozofii Ebnera, pozostaje w oczywistym konflikcie z tradycją liberalna, wedle której religia powinna usytuować się w granicach wyznaczonych dla niej przez rozum. Dosadniej na ten temat wypowiada się Kazimierz Ajdukiewicz, wybitny polski filozof, przedstawiciel szkoły lwowsko-warszawskiej ${ }^{16}$. Pisze on:

Daremnie więc usiłują racjonaliści przekonać mistyka i powstrzymać go od spełniania misji apostolskiej. Niemniej, głos racjonalisty jest zdrowym odruchem społecznym, jest aktem samoobrony społeczeństwa przed niebezpieczeństwem opanowania go przez niekontrolowane czynniki, wśród których może znajdować się zarówno święty, głoszący objawienie, jak również obłąkaniec głoszący wytwory swej chorobliwej umysłowości, jak wreszcie i oszust, pragnący dla niecnych i egoistycznych celów zyskać wyznawców dla pewnych poglądów i haseł. Lepiej jest pożywać pewną, choć skromną strawę rozumu niż w obawie, by nie przeoczyć głosu Prawdy, pozwolić na pożywanie wszelkiej nieskontrolowanej strawy, która może częściej jest trucizną niż zdrowym i zbawiennym pokarmem ${ }^{17}$.

To wszystko, co dotychczas powiedziałem, każe z dużą ostrożnością podejść do możliwości tradycyjnej edukacji religijnej. W świetle rozważań Ebnera

15 Jürgen Habermas, Między naturalizmem a religiq (Warszawa: Wydawnictwo Naukowe PWN, 2012), 205.

16 Szkoła lwowsko-warszawska skupiała uczniów Kazimierza Twardowskiego i była często porównywana do Koła Wiedeńskiego. W niektórych punktach program szkoły zbliżał się do neopozytywizmu, choć w innych zdecydowanie się od niego różnił.

${ }_{17}$ Kazimierz Ajdukiewicz, Zagadnienia i kierunki filozofii. Teoria poznania. Metafizyka (Kęty-Warszawa: Wydawnictwo Antyk - Fundacja Aletheia, 2003), 52. 
samo pojęcie takiej edukacji wydaje się wątpliwe. Jest takie, gdyż zakłada się w nim wprowadzanie dzieci i młodzieży w pewne doświadczenie, które według austriackiego myśliciela nie może być mediowane przez kulturę. Historycznie pojmowano edukację religijną jako przyswajanie sobie przez uczniów prawd wiary, czyli dogmatów religijnych; jej elementem było też tradycyjnie transcendentne uzasadnianie norm moralnych; wreszcie służyła ona za narzędzie legitymizowania władzy politycznej. Najczęściej spełniała i nadal spełnia wszystkie te trzy funkcje. Ebner krytycznie odnosił się do każdej z nich. Język dogmatów religijnych postrzegał jako coś martwego i przeciwstawiał mu żywe Słowo umożliwiające dialog między dwojgiem ludzi; normy moralne rozumiał w ich społecznym osadzeniu; zaś legitymizowanie władzy politycznej oceniał jako najbardziej niepożądaną funkcję religii. Jeżeli ta zakorzeniona w kulturze edukacja religijna nie jest $\mathrm{w}$ stanie otworzyć jednostki na realności duchowe, to co byłoby w stanie to uczynić? Innymi słowy, jak można by wyobrazić sobie edukację religijna, która zaszczepiałaby w uczniach zasadę dialogiczną?

Ebnerowska filozofia dialogu spotyka się w tym punkcie z teologią krytyków kultury, zwłaszcza Karla Bartha. Odwrócenie się od świata i zwrócenie się ku Słowu, oto co zaproponował Barth i co w istocie proponuje także Ebner. Jak długo jednostka zwraca się do świata, mówi sama do siebie i żyje w iluzji. Cała edukacja religijna realizowana w tym kontekście jest rodzajem snu. Dopiero gdy jednostka zwróci się ku Słowu, w wierze, że jest to Słowo skierowane do niej, Słowo znaczące i realnie zmieniające jej życie, jest ona w stanie obudzić się ze snu i znaleźć szczęście. Edukacja religijna powinna zatem być przede wszystkim studiowaniem Słowa, zbliżaniem się poprzez nie do prawdy i miłości. Otwarcie się na Słowo pozwala jednostce zobaczyć, kim jest ona sama i kim jest drugi człowiek. $Z$ praktycznego punktu widzenia należałoby zapytać, czy tego rodzaju edukacja jest w ogóle wyobrażalna. Odpowiedź jest pozytywna. Wiele szkół we współczesnym świecie, także świecie liberalno-demokratycznym, realizuje tego rodzaju edukację. Są to szkoły wyznaniowe, zakładane i prowadzone zazwyczaj przez konserwatywnie nastawionych chrześcijan, żydów, muzułmanów. Studiuje się w nich święte księgi uznawane za Boże objawienie. Pieczołowitość w organizowaniu tych studiów i troska o czystość przekazywanej wiedzy wynikają także z przekonania o istnieniu zasadniczego napięcia między religią a kultura, niezgody między tym, czego uczy religia, a tym, do czego przekonuje kultura, łącznie z rozwijaną w niej nauką. Szkoły tego rodzaju funkcjonują na marginesie głównego nurtu edukacyjnego, a ich twórcy bardzo dbają o to, aby programy tych szkół nie były w jakikolwiek sposób kontrolowane przez 
Państwo. Państwo ze swojej strony akceptuje istnienie takich szkół i nie ingeruje w ich działalność.

Filozofia Ebnera była protestem przeciwko ujednolicającej kulturze, w której relacje między Ja i Ty są zastępowane relacjami między ja a ludzkością czy klasą społeczną. Był to protest $w$ imię religii i dostrzeganych w jej ramach realności duchowych. Ebner poprzez swoją filozofię dialogu wchodził w spór z nowym typem kultury, w którym autentyczność i niepowtarzalność osoby są niszczone przez bezimienny formalizm i dążenie do ujednolicenia ludzi i rzeczy. Podobne głosy protestu podnosił przed Ebnerem Kierkegaard, a wśród współczesnych Ebnerowi - Emanuel Mounier. Interesujące jest, że wszyscy ci myśliciele, w poszukiwaniu obrony przed zagrożeniami płynącymi z kultury, zwracali się do religii. Ebner wprost, wskazując na rangę Słowa w relacjach między osobami, odwołuje się do Ewangelii.

W niniejszym tekście pokazałem, że te odwołania miały charakter specyficzny. Kierowały się one do pewnego typu religii i właściwego dla niego doświadczenia. W rezultacie dialog, o jakim mówi Ebner, ma ograniczone możliwości realizacji. Może być sensownie rozwijany tylko w kontekście wiary religijnej i tylko między dwojgiem osób. To jest według mnie pewna słabość tej koncepcji, ujawniająca się szczególnie współcześnie, gdy w państwie liberalno-demokratycznym rozwijany jest zupełnie inny dialog. Problem edukacji religijnej, do którego nawiązałem na końcu, jest wymownym przykładem trudności wpisanych w myśl Ebnera. Z drugiej strony trudno odmówić Ebnerowskim analizom przenikliwości i odwagi. Tym, co szczególnie zasługuje na uznanie, jest, moim zdaniem, pokazanie przez niego uwikłania religii w politykę. Bezkompromisowa krytyka sojuszu Tronu z Ołtarzem, ujawniająca się w jego pismach, każe ponownie zwrócić się do religii indywidualistycznej i w niej szukać pocieszenia w czasach kryzysu, także wówczas, gdy odwracają się od nas ci, którzy reprezentują czy to Tron, czy Ołtarz.

\section{Ferdinand Ebner and the Paradox of Solitude (Summary)}

The text raises the issue of dialogue as a religion experience in the expression of an Austrian thinker, Ferdinand Ebner. Religious experience as an escape from a declining culture is characterized as a subjectively experienced encounter with 
the Word of God and the word of the other. That experience is then confronted with dialogue as it is understood by the liberal-democratic state. Thanks to that confrontation a tension between maximalist and minimalist approaches to dialogue has been enhanced. The whole of the analyzes shows the paradox of solitude emerging from Ebner's thought and at the same time leads to ask important questions regarding the shape of religious education in contemporary society.

Key words: Ebner; dialogue; religious experience; the liberal-democratic state; religious education.

\section{Ferdinand Ebner i paradoks samotności (Streszczenie)}

Tekst porusza kwestię dialogu jako doświadczenia religijnego w ujęciu austriackiego myśliciela, Ferdinanda Ebnera. Doświadczenie religijne, jako ucieczka od upadającej kultury, charakteryzowane jest jako przeżywane subiektywnie spotkanie ze Słowem Boga i słowem drugiego człowieka. Doświadczenie to jest następnie konfrontowane $\mathrm{z}$ dialogiem $\mathrm{w}$ rozumieniu państwa liberalno-demokratycznego. Dzięki tej konfrontacji uwypuklone zostaje napięcie między maksymalistycznym a minimalistycznym podejściem do dialogu. Całość analiz pokazuje paradoks samotności wyłaniający się z myśli Ebnera i jednocześnie prowadzi do postawienia istotnych pytań o kształt edukacji religijnej we współczesnym społeczeństwie.

Słowa kluczowe: Ebner; dialog; doświadczenie religijne; państwo liberalnodemokratyczne; edukacja religijna.

\section{Bibliografia}

Ajdukiewicz, Kazimierz. Zagadnienia i kierunki filozofii. Teoria poznania. Metafizyka. Kęty-Warszawa: Wydawnictwo Antyk - Fundacja Aletheia, 2003.

Ebner, Ferdinand. Stowo i realności duchowe. Fragmenty pneumatologiczne, thum.

Krzysztof Skorulski. Warszawa: Wydawnictwo IFiS PAN, 2006.

Habermas, Jürgen. Między naturalizmem a religia, thum. Maciej Pańków. Warszawa:

Wydawnictwo Naukowe PWN, 2012.

Habermas, Jürgen. Teoria działania komunikacyjnego, thum. Andrzej M. Kaniowski. Warszawa: Wydawnictwo Naukowe PWN, 1999. 
Horowski, Jarosław. Wychowanie moralne wedlug pedagogiki neotomistycznej. Toruń: Wydawnictwo Naukowe Uniwersytetu Mikołaja Kopernika, 2015.

Johnston, William M. The Austrian Mind. An Intellectual and Social History 1848-1938. Berkeley-Los Angeles-London: University of California Press, 1983.

Micińska, Magdalena. Inteligencja na rozdrożach 1864-1918. Warszawa: Instytut Historii PAN, Wydawnictwo Neriton, 2008.

O’Donnell, John. „The Trinity as Divine Community”. Gregorianum 69 (1988): 5-34.

Rawls, John. Teoria sprawiedliwości, tłum. Maciej Panufnik, Jarosław Pasek, Adam Romaniuk. Warszawa: Wydawnictwo Naukowe PWN, 1994.

Russell, Bertrand. Dzieje filozofii Zachodu, tłum. Tadeusz Baszniak, Adam Lipszyc, Michał Szczubiałka. Warszawa: Fundacja Aletheia, 2000.

Skorulski, Krzysztof. „Ferdinand Ebner i miejsce filozofii dialogu w myśli katolickiej XX wieku". Paedagogia Christiana 1 (2011): 49-68.

Skorulski, Krzysztof. „Od ideologicznej samotności do dialogicznego spotkania: F. Ebner, L. Althusser, P. Freire". Forum Oświatowe 1 (2014): 15-35.

Stewart, John. „Przedmowa”. W: Mosty zamiast murów. Podręcznik komunikacji interpersonalnej, red. John Stewart, 15-22. Warszawa: Wydawnictwo Naukowe PWN, 2003. 
